ISSN 1991- 8690

website :http:// jsci.utq.edu.iq

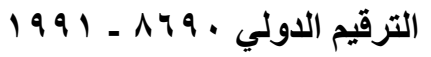

Email: utjsci@utq.edu.iq

\title{
Prevalence of anti-HBV antibodies in multi-transfused patients with thalassemia at Thi- Qar province
}

\author{
Bushra Jabbar Al-Badry \\ Manal Badi Al-Tamemi \\ Sciences College -Thi-Qar University
}

\section{$\underline{\text { Abstract }}$}

The present study was carried out from September 2012 to May 2013 to detect the epidemiology of Hepatitis B virus infections among the Thalassemia patients, represent patients referred to the center of thalassemic /AL-Haboby Hospital, central blood bank, at Thi-Qar province. The ELISA-III technique was implemented. This study was conducted on 457 individuals from thalassemic patients: 252 males and 205 females. Seropositive results of HBV by ELISA III technique was found in $5(1.09 \%)$, the infections were distributed as the following: males $4(1.58 \%)$ were higher than females $1(0.48 \%)$, with significant differences $(\mathrm{P} \leq 0.01)$. The statistical analysis showed significant differences in urban than rural parts of the province $(\mathrm{p}<0.01)$. The highest infection rates recorded was $2.38 \%, 1.11 \%$ and $1.02 \%$ at age groups $11-15,16-20$ and $>21$ years) respectively.Our results have revealed that hepatitis B vaccine is highly immunogenic for children with thalassemia and particularly well tolerated. According to our findings most thalassemic patients (98.91\%) were immune to HBV and $1.09 \%$ of them were not immune to HBV.

Keywords : HBV, Thalassemia, blood transfusion, transfusion transmitted infection, Thi-Qar

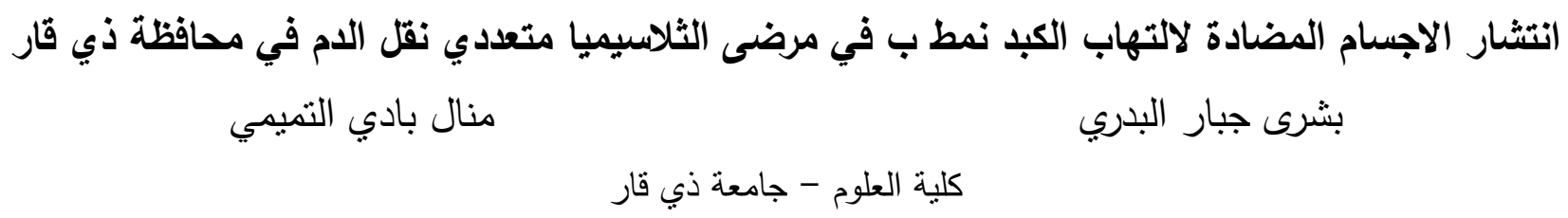

$\underline{\text { الخلاصة }}$

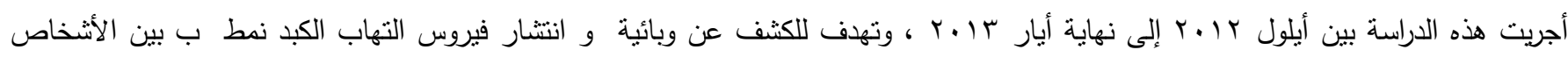

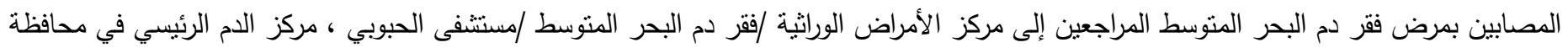

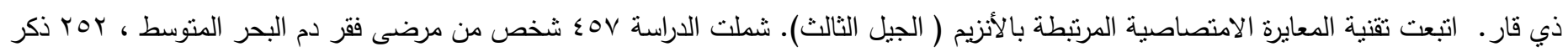

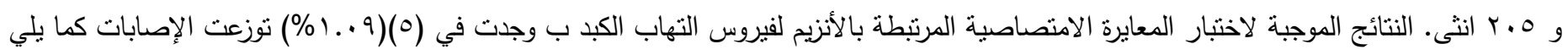

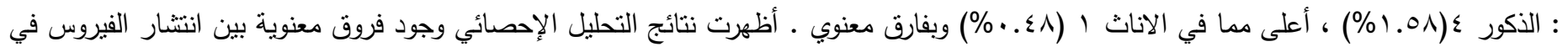

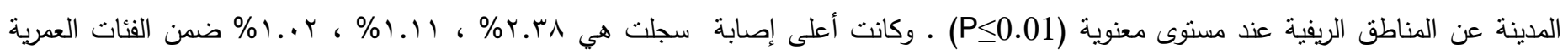

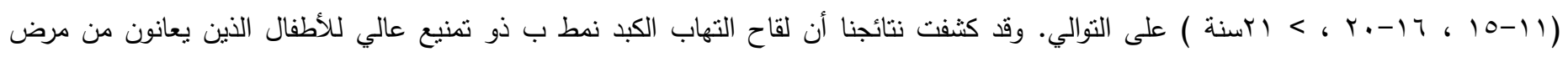

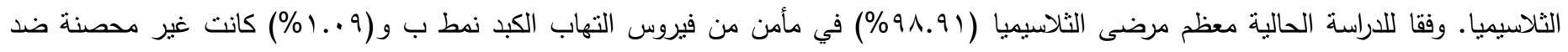

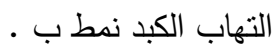

\section{Introduction}

Thalassemia is one of the most common genetic diseases in the world. It is a major health problem, brings much morbidity, early mortality and great deal of misery for a family both financially and emotionally(1). There are more than 2 billion people with hepatitis $B$ infection worldwide with 350 million people as hepatitis B virus carriers. Patients with thalassemia major should receive blood transfusion regularly to maintain optimal hemoglobin $(\mathrm{Hb})$ level. They do not survive for more than 5 years without blood transfusion(1,2). Among blood transfusion hazards, blood born virus infections are very important. These include HIV( risk of progression to AIDS which is untreatable), Hepatitis B virus and Hepatitis $\mathrm{C}$ virus which may lead to chronic hepatitis, liver cirrhosis and 
hepatocellular carcinoma (5). Hence, prevention in this high risk group is of great importance $(3,8)$. On the other hand, thalassemic patients may have iron overloading due to chronic blood transfusion which could lead to impaired immune response toward vaccination(4). Therefore, determination of immune response in multi-transfused patients is very important.

This study was aimed to determined the prevalence of HBV among blood transfused thalassemia patients at Thi-Qar province.

\section{Subjects and Methods}

Patients: A total of 457 individuals referred to the center of thalassemia / AL-Haboby hospital who had received here doses $(10 / 20 \mu \mathrm{g})$ of recombinant HBV vaccine in months 0,1 and 6 were selected. These patients were diagnosed at virology lab of central blood bank during 2012-2013. The study population included 252 males and 205 females, aged 1 to $>21$ years. On the basis of their age, the patients were classified into 5 groups of 1-5, 6-10, 11-15, 16-20 , > 21years old.

ELISA test: Serological markers of HBV infection such as HBs-Ag (anti- HBs) were tested using commercial enzyme linked immunosorbent assay (ELISA) kit (BioElisa , Spain ) according to the instructions of the manufacturer (6).

\section{Statistical analysis}

Analysis of data was done by using a computer with the available statistical packages for social scienceversion 11 (SPSS). LSD was used to assess these significant differences at level $\mathrm{p}<0.01$ (7).

\section{Finding and Discussion}

The present study was revealed that out of 457 individuals of thalassemia patients from different regions of Thi-Qar province, $5(1.09 \%)$ of those gave positive result for HBV by ELISA III technique. Although patients were taking the vaccine, its recorded positive cases of Hepatitis B virus, because patients may have iron overloading due to chronic blood transfusion which could lead to impaired immune response toward vaccination(4). Our results showed that HBV vaccine is immunogenic and safe in multitransfused thalassemic patients. The infections with HBV among males $4(1.58 \%)$ were higher than females $1(0.48 \%)$, with significant differences $(\mathrm{P} \leq 0.01)$ (Table 1).
Table (1) Seroposivity of HBV infection relation to gender

\begin{tabular}{|c|c|c|}
\hline Gender & $\begin{array}{c}\text { Total } \\
\text { number }\end{array}$ & No. of infection \\
\hline Males & 252 & $4(1.58 \%)^{\mathrm{a}}$ \\
\hline Females & 205 & $1(0.48 \%)^{\mathrm{b}}$ \\
\hline L.S.D & & 0.12 \\
\hline
\end{tabular}

Serologic tests for detection of HBV antibodies are important first-line tests in screening and diagnosis of HBV infection. The presence of anti-HBV antibody in serum and plasma reflect exposure to the virus and may indicate an acute, chronic, or resolved infection (8).

Blood transfusion, medical staff, which considered the main reasons of HBV transmission followed by injection of drugs, and may be dental surgery of the thalassemia patients and from mother to child (11).

The high percentage of infections in males in comparison with females may be related to the causes of this variation to genetic factors related to the willingness of any of the sexes to infection according to the virus (9). Also the sex hormones have effects on infection as indicated by Soulsby, (1982) who explained that male hormones cause decreasing cellular immunity, while female hormones cause increasing (10).The statistical analysis showed significant differences $(\mathrm{P} \leq 0.01)$ between infections depending on age grade. The infections percentage recorded was $2.38 \%$ and $1.11 \%$ at age groups $11-15$ and (16-20and > 12 years) respectively, flowed by age group 6-10 years which showed the percentage $0.74 \%$, while no infection was recorded at the age groups 0-5 years, which was $0 \%$ (Table 2). 
Table (2) Distribution of HBV infection according to age group of patients.

\begin{tabular}{|c|c|c|}
\hline Age group (years) & Total number & No. of infection \\
\hline $0-5$ & 50 & $0(0 \%)^{\mathrm{d}}$ \\
\hline $6-10$ & 135 & $1(0.74 \%)^{\mathrm{c}}$ \\
\hline $11-15$ & 84 & $2(2.38 \%)^{\mathrm{a}}$ \\
\hline $16-20$ & 90 & $1(1.11 \%)^{\mathrm{b}}$ \\
\hline > 21 year & 98 & $1(1.02 \%)^{\mathrm{b}}$ \\
\hline L.S.D & & 0.115 \\
\hline
\end{tabular}

Exposure of thalassemia patient to the various medical device for treating and donation of blood is the leading cause of infection. On the contrary, age group 0-5 years that show no infection because they less exposure medical device for treating and donation of blood.

The present study confirmed that the HBV infections vary depending on geographical region and the results of the statistical analysis showed significant differences $(\mathrm{P} \leq 0.01)$. The highest percentage of infection was at Al-Nassiriyah (1.45\%) followed by AlShatra $(1.29 \%)$, Suq Al-shuyukh $(0.80 \%)$ and no infection at Al-Rifaay and Al-Jebaish as it is shown in (Table 3).

Table (3) Percentage of seropositivity infections of HBV of five regions at Thi-Qar province

\begin{tabular}{|c|c|c|}
\hline Region & Total number & No. of infection \\
\hline AL-Nassiryah & 206 & $3(1.45 \%)^{\text {a }}$ \\
\hline Suq Al-Shuykh & 125 & $1(0.80 \%)^{c}$ \\
\hline Al-Shatra & 77 & $1(1.29 \%)^{\mathrm{b}}$ \\
\hline AL-Rifaay & 50 & $0(0 \%)^{\mathrm{d}}$ \\
\hline AL-Jebaish & 0 & $0(0 \%)^{\mathrm{d}}$ \\
\hline L.S.D & & 0.2 \\
\hline
\end{tabular}

The pattern of spread of hepatitis B in the urban over the rural may be due to the people of the countryside to have a stronger immunity than who grow up in cities. fact that the urban's population is more evoluted and the large number of referred to the hospitals and exposure to the risk of infection due to contact with contaminated tools.

\section{Conclusion}

Our results have revealed that hepatitis B vaccine is highly immunogenic for children with thalassemia and particularly well tolerated. According to our findings most thalassemic patients $(98.91 \%)$ were immune to HBV (responders) and $1.09 \%$ of them were not immune to HBV (non-responders).

\section{Acknowledgment}

We are deeply grateful to all staff of central blood bank, thalassemic center/AL-Haboby Hospital in ThiQar province.

\section{References}

1. Choudhury, N. and Phadke, S. (2001). Transfusion transmitted diseases. Ind J Pediatr. 68(10):951-8.

2. Mollah, A.H.; Nahar, N.; Shiddique, M.A.; et al., . (2003). Common transfusion-transmitted infectious agents among thalassemic children in Bangladesh. J Health Popul Nutr. 21(1): 67-71.

3. Ansari, S.H.; Vosough, P.; Moeini, B.; et al., .(2004). The effective factors on anti-HBs titer after vaccination in beta-thalassemic patients. Iran Red Crescent Med J. 2(7):23-6.

4. Farmakis, D.; Giakoumis, A.; Polymeropoulos, E.; et al., . (2003). Pathogenetic aspects of immune deficiency associated with beta-thalassemia. Med Sci Monit. 9(1):RA19-22.

5. Mirmomen, S.H.; Alavian, S.M.; Hajarizadeh, B.; et al., .(2006). Epidemiology of hepatitis B, hepatitis $\mathrm{C}$ and human immunodeficiency virus infection in patients with beta-thalassemia in Iran: A multicenter study. Arch Iranian Med. 9(4):319-23.

6. Countreras, M. and Barbara, J. (1989). Screening for hepatitis $\mathrm{C}$ antibodies. The Lancet., $2: 505$.

7. Newman, S.C.( 2001). Biostatistical Methods in Epidemiology. $7^{\text {Th }}$ Ed. John Wiley \& Sons, Inc. New York. P. 72-77.

8. Mahy, W.J. and Van Regenmortel, H.V. (2010). Desk encyclopedia of Human and Medical Virology. ELSEVIER. Spain. Pp : 113-120.

9. Okomoto, K.; Brook, M.G. and Gilson, R. (2005). Association of functional gene polymorphisms of 
matrix metalloproteinase (MMP)-1, MMP-3 and MMP-9 with the progression of chronic liver disease. J. Gastro. Hepatol., 20 : 1102-1108.

10. Soulsby, E.J. (1982). Helminthes Arthropoda and protozoa of domesticated animals. $6^{\text {th }}$ Ed. Monning Veterinary Helminthology and Entomology. Bailliere. Tindal and human being. Adv. Pediat. London. 1-60

11. Strauss, J.H. and Strauss, E.G. (2008). Viruses and Human disease. $2^{\text {nd }}$ ed. Elsevier. Canada. Pp : 120-122. 